\title{
Preliminary Notice on the Experimental Hybridization of Echinoids.
}

By

Cresswell Shearer, Walter De Morgan and H. M. Fuchs.

With 7 Text Figures.

INDEX.

I. Introduction and previous work.

II. Material.

III. Methods.

IV. Description of external characters of normal and hybrid larvæ:
a. $E$. esculentus $\delta \times E$. esculentus $\$$.
b. E. miliaris $\delta \times E$. esculentus $\$$.
c. $E$. miliaris $\delta \times E$.miliaris $\$$.
d. $E$. esculentus $\delta \times E$. miliaris $\$$.
e. $E$. acutus $\delta \times E$. acutus $\$$.

V. Characters of the skeleton.

VI. The chemical control of inheritance.

VII. The characters of the young sea-urchin.

VIII. Summary of conclusions.

\section{Introduction and Previous Work.}

THIs paper is a preliminary account of a series of experiments on the hybridization of Echinoids, first commenced by one of our number (De Morgan) at Plymouth in 1909, and which will form part of a larger work now approaching completion. This will comprise the hybridization of Echinus acutus, E. esculentus, and E. miliaris, together with an account of the cytology of the hybrid crosses and the control of paternal and maternal influence by chemical means.*

Within the last two decades a large amount of attention has been devoted to the problem of parental influence in Echinoderm hybrids. Most of this work has been done at Naples, where the majority of seaurchins seem to possess a longer breeding period than those of the colder waters of our own coasts. In America within the last year or two considerable attention has been devoted to this subject. In the hands of different observers, however, this work has led to very conflicting results, and has proved most indecisive in settling the main points at issue.

In 1889 Boveri (3) was the first to investigate the hybrids between

* The full paper will contain a large number of skeleton figures and drawings of Plutei and coloured plates of the hybrid urchins. The investigation of the cytology has been undertaken by L. Doncaster, and will form Part II of the paper.

NEW SERIES.-VOL. IX. No. 2. OCTOBER, 1911. 
different Echinoids, making use of Sphaerechinus eggs and Echinus sperms at Naples. He found that the hybrid larvæ were intermediate between those of the two parents. In 1894 Seeliger (16) made the same cross at Trieste, but found that many of his hybrids were of the purely paternal type; thus contradicting Boveri's result. In the following year Morgan (12) repeated this work, getting the same results as Seeliger. In 1895 Boveri (4) replied to Seeliger and Morgan substantiating his earlier results, but suggesting that at Trieste the Plutei had other characteristics from those at Naples. This does not apply, however, to Morgan's results obtained at Naples on the same material as that used by Boveri.

In the same year Vernon (19) commenced a new era in the work by a thorough investigation of the effects of environment on the larvæ. In 1898 he followed up his first work with the investigation of inheritance in various hybrid forms. He made crosses between Sphaerechinus, Strongylocentrotus and Échinus. His hybrid larvæ were mostly maternal, but some species seemed to have a greater capacity for transmitting their characteristics than others. In the same year Driesch (6) crossed Strongylocentrotus, Sphaerechinus, Echinus, and Arbacia and obtained hybrid larvæ of a purely maternal type.

In 1900 Vernon (21) hybridized Strongylocentrotus and Sphaerechinus at Naples and claimed to find that the parental influence in the resulting hybrids varied with the season of the year at which the experiments were made. In spring they resembled Strongylocentrotus, while in summer they were like Sphaerechinus. In the latter case, however, none of the larvæ were of the pure Sphaerechinus type. He suggested that this variation was due to a seasonal fluctuation in the relative ripeness of the sexual products.

In 1902 Steinbrück (17) studied the cross Strongylocentrotus of $\times$ Sphaerechinus o and came to the conclusion that, while there was a seasonal variation in dominance, it was not due to the relative ripeness of the eggs and sperm, but to changes in temperature; for, by raising the temperature of the water in which his larvæ were kept, in the spring he caused them to assume the summer form. In the same year Driesch (7) did some further work on the hybridization of Strongylocentrotus, Sphaerechinus, and Echinus, and substantiated his earlier results of maternal influence.

In 1906 Fischel (8) working at Villefranche, crossed Arbacia, Echinus, and Strongylocentrotus and contradicted Driesch, finding that the sperm had an important influence and that the hybrids showed undoubted paternal characters, although these were, he admitted, of a very minor degree as compared with the maternal. 
In 1909 Hagedoorn (9), working in Loeb's Laboratory, Pacific Grove, Cal., crossed Strongylocentrotus purpuratus and $S$. franciscanus and found a purely motherly dominance in the shapes of the skeletal apical rods. In the following year Loeb, King, and Moore (10) repeated these experiments at the same place, but reached very different results. They came to the conclusion that each character was inherited separately, that is, quite apart from whether it is of maternal or paternal origin: that of a pair of allelomorphic characters one is invariably dominant over the other in the hybrid: that the characters of the Pluteus are inherited on strictly Mendelian lines. Thus, for instance, they found the club-shaped ends of the skeletal rods to be dominant over the arched form, the round, dome-shape of the larvæ to be dominant over the pyramidal, the rough spinous character of the skeletal rods dominant over the smooth, and so on through a number of characters. They made no attempt to rear their larvæ to metamorphosis and to follow these characters in the later stages, neither did they attempt to trace, if possible, the characters in the later generations, in the usual Mendelian manner.

Lastly, Tennent (18) working at the Tortugas Laboratory, off the coast of Florida, in the midst of the warm water of the Gulf Stream, crossed among other forms Toxopneustes and Hipponöe, always finding his hybrids to resemble Hipponöe. He then altered the concentration of the $\mathrm{OH}$-ions in the seawater in which the cross was made, and found by this means that the dominance was changed to the Toxopneustes side. Here again, as in all the previous work, it is doubtful if characters sufficiently definite have been adopted as an index of parental influence. For instance, the skeletal support of the postoral arm of Toxopneustes is a single rod, whereas in Hipponöe it is a lattice structure. If, in his hybrids, more than one rod appeared in the arm, Tennent considered it as an indication of Hipponöe influence. But as previous observers have noted, and we have repeatedly found in our own experiments, extra rods appear, under unfavourable conditions, even in forms which do not normally possess them.

From the above brief review of the subject, it is plain that the opinions expressed by the different investigators have been most conflicting, and that the conclusions they have drawn have been, in many instances, diametrically opposite to one another, although the work was frequently done with the same material. This is in great part due to the uncertain nature of the evidence on which these results have been based, evidence which has been drawn from the early development alone. No successful attempt has been made to rear the hybrids, in order to follow the nature of the parental influence in the 
later and less variable stages. The chief index of paternal or maternal influence has been the skeleton; but this, unfortunately, exhibits a large amount of irregular variation dependent on small metabolic changes, a variation in many cases quite independent of heredity.

The present work was commenced, therefore, with the object of discovering fixed specific characters, into which we felt certain no irregular variation entered. After considerable investigation we came to the conclusion that these could only be looked for in the later period of larval life. For in our experiments we have found that every culture jar had its own rate of development and showed minor variations with regard to the early larval characters, such as skeleton, pigmentation, and shape, so that it was plain that no definite results could be hoped for from the investigation of young stages alone.

Thanks to the methods elaborated by Dr. Allen (1) of rearing marine larvæ and of feeding them on pure cultures of diatoms from which bacteria and infusoria are as far as possible eliminated, and of keeping the larvæ in sterilized sea-water, it is now possible to rear the Plutei of Echinoids with great facility through metamorphosis to the young fully formed Sea-Urchin.* This suggested to us the idea of making a full investigation of the later stages of the pure and hybrid forms, and we hope to show that we have found in them immutable and distinct specific characters which give much more definite evidence than those hitherto used in this work.

We have chosen Echinus acutus, E. esculentus, and E'. miliaris as the three commonest forms on our coasts, and also for the reason that we already possess in MacBride's work (1) a clear account of the main features of the normal development of these species. Of these three forms, $E$. acutus and $E$. esculentus at Plymouth are found in deeper water, while $E$. miliaris is a shore species. It is therefore highly probable that laboratory conditions are more favourable to the latter than to the two former; and this would seem to be borne out by the fact that $E$. miliaris develops, under laboratory conditions, much more quickly than the other two, and that in all crosses into which $\boldsymbol{E}$. miliaris enters the rate of development is accelerated.

While there are marked specific differences between E. miliaris $\dagger$ (which has by some authors been placed in a separate genus, Par-

\footnotetext{
* While previous investigatorshave unsuccessfully attempted to rear hybrid Plutei through metamorphosis, Doncaster (5), making use of the cross Strongylocentrotus lividus of $\times$ Echinus microtuberculatus $q$, seems to have been the first to have accomplished this. One of the present authors (Shearer) had the opportunity in 1902 of examining these hybrids at Naples.

+ It may be here noted that $E$. miliaris, on the Devonshire coast, exhibits several distinct varieties, which differ chiefly in size, in length of spines, and in pigmentation.
} 
echinus) and $E$. esculentus or $E$. acutus, there is much less distinction between the two latter, which we suspect to be merely varieties of one and the same species, although according to Bell (2) the number and disposition of the plates differ considerably. We were quite unable, from a superficial examination, to tell to which species a large number of specimens, brought into the laboratory during the course of our experiments, belonged. In shape and character of their spines they were as much $E$. esculentus as $E$. acutus, and without a close examination of their plates it was quite impossible to identify them.

In the "Ingolf" Echinoidea I (14), Mortensen mentions some specimens, which "combine to a curious degree the character of both E. esculentus and acutus, var. Flemingii, so that it is quite impossible to decide with certainty to which of these species they belong, and the supposition of their being hybrids between the two species seems very obvious." In his recent paper (15) he gives a photograph of one of these supposed hybrids, with a description. We ourselves have long suspected that such hybridization must take place between $E$. esculentus and E. acutus at Plymouth, where they live side by side on the same beds, their breeding periods overlapping very considerably. If crossing between these two forms is such an easy matter in the laboratory, why should it not take place in a state of Nature? This is a question that has also been raised by Doncaster (5). We believe that considerable hybridization does take place, and the forms to which we have drawn attention above, and which agree in many respects with the one figured by Mortensen (15), seem to bear out this conclusion. In our full paper we shall give photographs and go into details of the plates of these intermediate forms.

Mortensen (15) also gives a figure of a form which he considers to be a cross between $E$. esculentus and $E$. miliaris. We have already mentioned in a footnote, page 124 , that there are several varieties of E. miliaris at Plymouth, and one of these bears a considerable resemblance to Mortensen's supposed hybrid. This variety differs, however, in the character of its spines from the young hybrids of this cross which we have reared.

We have been unable to detect differences between the larvæ of $E$. esculentus and $E$. acutus, except that the skeletal apical rods of the latter are more robust and less arched than those of the former. For this reason, in the present paper, we have not considered in any detail the development of $E$. acutus, beyond pointing out that, when crossed with E. miliaris, it behaves similarly to E. esculentus. In our forthcoming paper we will go into these points in full.

We have tried to eliminate from our cultures, as far as possible, all 
abnormal or unhealthy Plutei. No drawings or observations have been made of any such larvæ, and all crosses showing an unusually large percentage of abnormalities have been thrown away and the experiments repeated. It is remarkable, however, how frequently abnormalities, especially with regard to the development of the arms and skeleton, are to be seen in Plutei taken from the Plankton.

Although we have had no difficulty in rearing Plutei in considerable numbers through metamorphosis, and some of our young hybrid urchins are now, after two years, one centimetre in diameter,* we have not succeeded so far in bringing them to a stage of sexual maturity. This is doubtless due to the fact that we have been unable to furnish them with the proper food. For it would seem, from what we have been able to discover regarding $E$. miliaris, that individuals of this species at least can become sexually mature within the first year of their existence, in a state of nature, and can attain the size of some six centimetres. As none of the E. miliaris hybrids in our cultures in the laboratory have shown any such rapid rate of growth, we feel that we have only partially succeeded in our feeding methods.

During the first few weeks after metamorphosis the young Echini thrive readily on the "red weed" (Delesseria), but after this they soon cease to grow, and evidently at this stage a further change of food is necessary. What exactly this change should be we have so far been unable to find out, and we have simply allowed them to remain in culture jars in the hope that they will find their proper food among the algae growing there.

It is the ultimate object of our work to bring the hybrid urchins to sexual maturity and, if possible, investigate the characters of the second generation. Our experiments of the last three years seem to point to the improbability of accomplishing this under laboratory conditions, and we are at present devising a method for confining our young hybrid urchins on the sea bottom in their natural habitat.

It is obvious, however, that all laboratory conditions differ in many essentials from those obtaining in nature. For this reason we have, this year, raised Plutei from the first in the sea, by confining them in jars in the chambers of a floating box, which is anchored some miles out, in the clearer water of Plymouth Sound. We have not noticed that our Plutei reared under these conditions grow more rapidly than those kept in the Laboratory, and this would seem to be due to the lack of food. It seems to be impossible to get any protected water where the Plutei might be confined, as rich in the Diatom

* One hybrid, raised at Cambridge, is now $3 \mathrm{~cm}$. in diameter. For figures of same, vide Nature, Vol. LXXXVII, p. 111, 1911. 
flora as that of the rapidly changing tidal waters that sweep over the beds where the Echini find their natural habitat. Nevertheless a number of the Plutei reared under these conditions have metamorphosed.

\section{MATERIAL.}

The experiments were commenced in the Laboratory of the Marine Biological Association, Plymouth, in 1909, and continued through 1910 and 1911. Similar results were obtained from each series of experiments.

Echinus esculentus and $E$. acutus are obtainable at Plymouth in fairly large quantities by trawling in depths of about 25 fathoms.

Echinus miliaris is a shore species. It is not so numerous as the other species, and can only be collected at very low tides.

The percentage of ripe Echini in a haul is small. The quantity of material consumed was consequently large, and our thanks are due to Dr. Allen and the staff of the Laboratory for the trouble taken to provide us with a constant supply of material.

To ensure successful fertilization it is essential that the sperm and ova should be thoroughly mature. Partially ripe sperm and ova are capable of fertilizing, and of being fertilized, but the larvæ of such a union do not develop normally, and seldom reach a late stage, although they may remain alive for many days.

It might be assumed that the ideal condition would be to use Echini on the point of discharging their genital products, and such under normal conditions would be correct, but we have frequently noticed that under irritation or when in an unhealthy condition the animals discharge their sperm and ova. In a few instances we have observed them discharging in vast quantities when in a moribund condition, the urchins dying afterwards within a few hours. It is almost unnecessary to add that, when eggs or sperm, shed in this manner, are brought together, fertilization either fails to take place, or the resulting Plutei are abnormal and unhealthy.

If a ripe ovary is gently shaken in water, the ova will float away without any or but a small quantity of follicular tissue. Rough shaking should be avoided, as by it many partly ripe and immature eggs will be detached. The ovary from which the greatest number of eggs is obtained with the least agitation, and the least admixture of the tissue, will generally be found to give the best result. Under the microscope the nuclei of such eggs will not be visible.

It is more difficult to judge the ripeness of the spermatozoa, as they are motile some time before they are actually mature. The mature 
male gonad when torn exudes a milky fluid, which under the microscope appears to seethe with vibratile spermatozoa; but it is obviously difficult to compare the relative rapidity of motion in sperms from different individuals.

\section{METHODS.}

A portion of a ripe ovary was placed in a finger bowl containing either "outside water" or "Berkefeld water." *

As soon as the ova floated out, the piece of ovary and any pieces of tissue were removed and a small quantity of a culture of sperm added. Excess of sperm should be avoided, as it speedily fouls the water, which should be changed if it appears milky. If sperm and ova were ripe, the fertilization membrane was thrown out in a few minutes, and segmentation followed. In about twenty-four hours free-swimming blastulae appeared. These were removed to jars containing about $2000 \mathrm{cc}$. of Berkefeld or outside water. A couple of small pipettesfull of a culture of the diatom Nitschzia closterium were then added for food, and the blastulae left to develop.

All the usual precautions for sterilizing jars, pipettes, scissors, etc., were rigidly observed, and before being opened the Echini were immersed in tap water to destroy any sperm adhering to the test. In all experiments proper controls were kept, and in any case where these went wrong the entire batch of material was thrown away and the experiment repeated.

\section{DESCRIPTION OF EXTERNAL CHARACTERS OF NORMAL AND HYBRID LARVÆ.†}

\section{(a) EARLY DEVELOPMENT OF $\frac{\text { E. ESCULENTUS o }}{\text { E. ESCULENTUS }}$}

The four-armed pluteus stage is reached in about four to six days from date of fertilization. It then has a symmetrical body, well rounded at the posterior pole, with slender arms, longer than the depth of the body. It is slightly pigmented. A few days later (from seven to nine days) the third pair of arms (postero-dorsal) appears, and between the second and third weeks the anterior epaulettes. The

* In using the term "outside water," we mean water brought into the Laboratory in 3-4 gallon glass carboys, collected outside the Plymouth Breakwater in the tidal water of the English Channel, and therefore three or four miles from land. These flasks are always allowed to stand for four or five days in the Laboratory before being used, thus ensuring the absence of live sperm. By "Berkefeld water" we mean ordinary Laboratory tank-water, which is of considerably lower alkalinity than "outside water," which has been treated with animal charcoal, aerated and filtered through a Berkefeld filter and then stored in sterilized flasks. See Allen and Nelson (1).

+ The nomenclature used in this paper is that of Mortensen (13). 
pluteus has still a rounded posterior pole, but the arms are longer in proportion to the depth of the body. About this time the invagination which will form the oral dise of the future Echinus appears. At the end of about a fortnight the fourth pair of arms is formed, and about this time the posterior pole begins to flatten until it assumes the appearance of Figure 1. In about three weeks the posterior epaulettes are well advanced, and the pedicellariae have appeared.

It may be here stated that the times given for the appearance of different organs are only very approximate. There is the widest difference in rate of development not only between the individuals in each jar, but between the larvæ of separate cultures reared from ova and sperm of the same Echini under apparently the same conditions.

external Characters of late larva (Fig. 1).

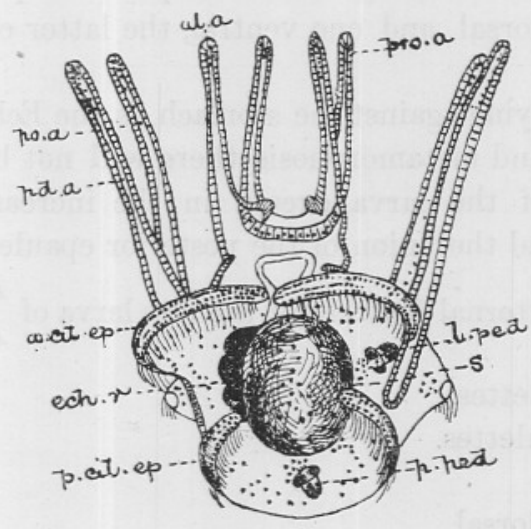

Fig. 1.-Larva of $E$. esculentus $\delta \times E$. esculentus $q$. Dorsal view. $\times 36.22$ days old. The specimen is tilted forward so that the posterior surface is shown. a. cil. ep. - Anterior ciliated epaulette. al. a. - Antero-lateral arm. ech. r.-Echinus rudiment. $l$. ped.-Lateral pedicellaria, pro. a.-Preoral arm. p. cil. ep.-Posterior ciliated epaulette. p. ped.-Posterior pedicellaria. pd. a.-Postero-dorsal arm. po. a.-Post-oral arm. s.Stomach.

The body is rather deeper than wide, and the posterior pole somewhat flattened. It is studded with pigment spots of various shades from yellow to reddish brown, and of various shapes and sizes. In the specimen from which the drawing was made the body was regularly pigmented, while little, if any, pigment appears on the arms except at the extremities. Pigment, however, varies widely among individuals of the same culture in depth of colour and distribution, and this seems natural, since MacBride (11) has shown that the pigment is contained 
in wandering amoebocytes and is an excretory product in process of removal.

There are four pairs of long, slender arms, and along their edges run the ciliated bands. Around the anterior margin of the body are the "anterior ciliated epaulettes." These arise as four horizontally placed crescentic bands of cilia, constricted off from the main ciliated band, at the base of the post-oral and postero-dorsal arms. They gradually grow together, and before metamorphosis form a complete ring round the anterior pole of the body. In the figure they have not yet united dorsally. They are spotted with brown pigment, and carry powerful cilia, which in these late stages are the principal means of locomotion. At the posterior end are the "posterior ciliated epaulettes." These are pigmented and ciliated like the anterior epaulettes, and eventually will extend round the posterior pole of the larva.

There are three pedicellariae: one at the posterior pole, and two on the right side, one dorsal, and one ventral, the latter of which is not seen in the figure.

On the left hand, lying against the stomach, is the Echinus rudiment. Between this stage and metamorphosis there will not be much change in the appearance of the larva, except in the increased size of the Echinus rudiment and the union of the posterior epaulettes.

Thus the salient external features of the late larva of $\frac{\text { E. esculentus } ~}{\text { E. esculentus } q}$ are:-

The anterior epaulettes.

The posterior epaulettes.

Three pedicellariae.

One right side dorsal.

One right side ventral.

One at the posterior pole.

\section{(b) EARLY DEVELOPMENT OF $\frac{\text { E. MILIARIS \& }}{\text { E. ESCULENTUS } ?}$}

There was a good deal of variation among the four-armed plutei of this hybrid. The majority inclined to the pointed, clear, lightly pigmented miliaris type, but did not develop a preoral lobe. On the other hand, there were some that showed distinctly esculentus characters. In the course of development the posterior pole becomes more rounded, and, when the anterior epaulettes were formed, either the larvæ were distinctly esculentus in shape, or intermediate between esculentus and miliaris. The posterior epaulettes did not show much advance until the end of the fourth week, by which time the right dorsal pedicellaria was well established. 
EXternal Characters of late larva (Fig. 2).

The body is not so wide as the pure $E$. miliaris, or so deep and flattened at the posterior pole as the pure $E$. esculentus. There is a good deal of brown pigment arranged in rather regular patches on the body, and also on the arms which are intermediate in form between the stumpiness of pure miliaris, and the length and slenderness of pure esculentus. The deeply pigmented anterior epaulettes

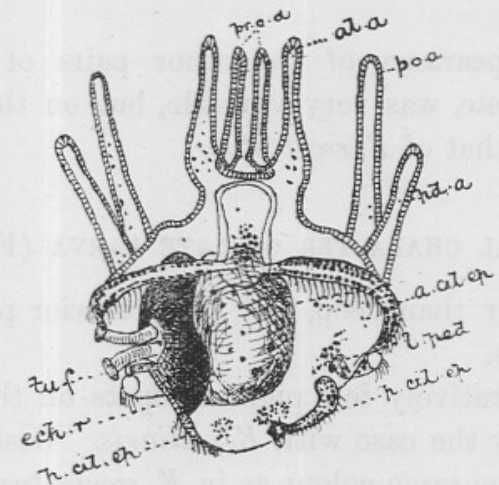

Fig. 2.-Larva of E. miliaris $3 \times E$. esculentus $\$$. Dorsal view. $\times 36$. 36 days old. This larva is more advanced than that shown in Fig. 1, and the tube-feet of the the young Echinus are protruded. tu.f.-Tube-feet. The remainder of the lettering as in Fig. 1.

have nearly surrounded the anterior margin of the body. The posterior epaulettes are not so far advanced. There are three pedicellariae, one at the posterior pole, and two on the right side, dorsal and ventral, the latter of which does not appear in the figure. On the left side is the young Echinus, well advanced, and with protruding tube-feet. The chief external features of this hybrid are:-

The anterior epaulettes.

The posterior epaulettes.

Three pedicellariae.

One right side dorsal.

One right side ventral.

One at posterior pole.

$$
\text { (c) EARLY DEVELOPMENT OF } \frac{\text { E. MILIARIS o }}{\text { E. MILIARIS }}
$$

The four-armed pluteus of $E$. miliaris is readily distinguished from that of E. esculentus. It is smaller, the posterior end is more pointed, 
and the arms are shorter as compared with the length of the body. It carries less pigment on the body than esculentus; and, in the early stages, there is often a very regular line of small pigment spots along the ciliated bands.

A marked preoral lobe overlies the mouth; and the larva generally presents a peculiar glassy, transparent appearance.

As the larva develops it retains its elongated form until about the time that the epaulettes appear. The posterior pole then gradually becomes more rounded, and finally assumes the shape depicted in Fig. 3.

The time of appearance of the other pairs of arms, epaulettes, Echinus rudiment, etc. was very variable, but on the average did not greatly differ from that of $E$. esculentus.

\section{EXternal Character of late larva (Fig. 3).}

The body is wider than deep, and the posterior pole more rounded than in $E$. esculentus.

There are comparatively few pigment spots on the body and arms, and this is generally the case with $E$. miliaris. Besides this pigment, which is of much the same colour as in $E$. esculentus, about the end of the third week, when the epaulettes are forming, a large mass of bright green pigment appears at the base of each. It always makes its first appearance at these points, but afterwards appears in spots on

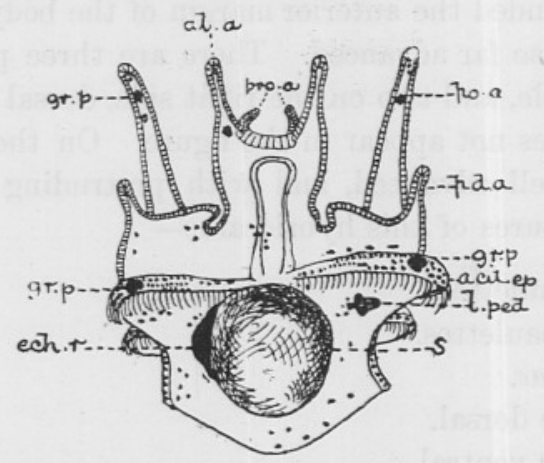

Fig. 3.-Larva of $E$. miliaris $\delta \times E$. miliaris 9 . Dorsal view. $\times 36.20$ days old. gr.p. - Green pigment. Other lettering as before.

the arms, and just before metamorphosis is widely diffused. This green pigment is not found in $E$. esculentus. The arms are shorter and more stumpy than in those of E. esculentus. 
There is only one set of epaulettes, the anterior, and they gradually close together and encircle the anterior pole of the body. They are dotted with yellowish brown pigment, generally of a lighter shade than in $E$. esculentus, and carry strong cilia.

There are two pedicellariae on the right side, one dorsal and one ventral; the latter not being shown in the figure. On the left of the stomach is the Echinus rudiment. Between this stage and metamorphosis there is not much change except in the size of the Echinus rudiment, and the amount of green pigment.

The chief external features are :-

Anterior epaulettes only.

Two pedicellarice.

One right side dorsal.

One right side ventral.

Masses of bright green pigment.

\section{(d) EARLY DEVELOPMENT OF $\frac{\text { E. ESCULENTUS o }}{\text { E. MILIARIS } \$}$}

The four-armed plutei differ but little from the pure E. miliaris larvæ of the same stage, excepting that they carry rather more pigment. A preoral lobe is present, but is not marked as in pure $E$. miliaris. The typical elongated $E$. miliaris shape is retained until about the time when the epaulettes make their appearance, when the posterior pole gradually assumes a flatter curve as in the figure.

\section{EXTERNAL CHARACTER OF LATE LARVA (FIG. 4).}

The body is not so deep, and the arms are longer than those of the pure $E$. miliaris, but the general appearance is very similar. The whole body, and the ciliated bands, are spotted with pigment of various shadès of reddish brown.

There is besides a large mass of green pigment at the bases of the epaulettes, and another mass of the same has appeared between their ends, and later on more will probably appear.

There is only one set of epaulettes, which ultimately encircle the anterior margin of the body. They are spotted with brown pigment and carry strong cilia.

There are two pedicellariae, one dorsal and one ventral, on the right side (the latter not shown in Fig. 4). 


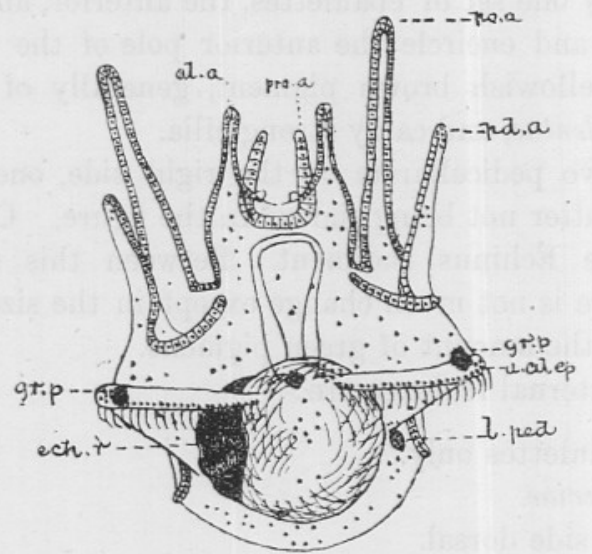

FIG. 4-Larva of $E$. esculentus $\delta \times E$. miliaris $\$$. Dorsal view. $\times 36$. Forty days old. Although it is twice the age of that shown in Fig. 3, there is little difference between them, except in size. Lettering as before.

This pluteus is twenty days older than the pure E. miliaris (Fig. 3), but beyond an increase in size there is little difference.

The chief external features of this hybrid are :-

The anterior ciliated epaulettes.

Two pedicellariae.

One right side dorsal.

One right side ventral.

Masses of green pigment.

(e) External Characters of THE LATE LaRve $\frac{E \text {. ACUTUS } \delta}{\text { E. ACUTUS } q}$

Regarding $E$. acutus and $E$. esculentus as distinct species, it might be expected that their late larvæ would show some marked specific differences. Such differences we have, however, been so far unable to discover. The late larva of $E$. acutus resembles that of $E$. esculentus in number and position of pedicellariae, of ciliated epaulettes and in the absence of green pigment. Superficially the larva of $E$. acutus has a smaller body and slenderer arms, with darker and more abundant pigment than that of E. esculentus, but hybrids between these species afford no criteria by which parental influence can be discriminated.

Hybrids, however, between $E$. acutus of and E. miliaris $q$ resemble those between $E$. esculentus $\delta$ and $E$. miliaris $\$$, in the absence of the posterior pedicellaria and of the posterior ciliated epaulettes and the possession of green pigment masses, while in the reciprocal 
cross the characters common to $E$. acutus and $E$. esculentus make their appearance.

SUMMARY OF LATE LARVAL CHARAC

\begin{tabular}{|c|c|c|c|c|c|c|}
\hline & $\begin{array}{c}\text { Anterior } \\
\text { epaulettes. }\end{array}$ & $\begin{array}{c}\text { Posterior } \\
\text { epaulettes. }\end{array}$ & $\begin{array}{c}\text { Green } \\
\text { pigment. }\end{array}$ & $\begin{array}{l}\text { Right dor- } \\
\text { sal pedicel- } \\
\text { laria. }\end{array}$ & $\begin{array}{l}\text { Right ven- } \\
\text { tral pedi- } \\
\text { cellaria. }\end{array}$ & $\begin{array}{l}\text { Posterior } \\
\text { pedi- } \\
\text { cellaria. }\end{array}$ \\
\hline$\frac{\text { E. esculentus of }}{\text { E. esculentus } q}$ & + & + & 0 & + & + & + \\
\hline$\frac{\text { E. miliaris of }}{\text { E. esculentus } q}$ & + & + & 0 & + & + & + \\
\hline$\frac{\text { E. miliaris ô }}{\text { E. miliaris } \uparrow}$ & + & 0 & + & + & + & 0 \\
\hline$\frac{\text { E. esculentus } \hat{d}}{\text { E. miliaris }+}$ & + & 0 & + & + & + & 0 \\
\hline
\end{tabular}

Considering only these six external characters the experiments of 1910-11 show that:-

1. The egg of Echinus esculentus fertilized by its own sperm produces a late larva having anterior epaulettes, posterior epaulettes, no green pigment, one right side dorsal pedicellaria, one right side ventral pedicellaria, one posterior pedicellaria.

2. The egg of Echinus esculentus fertilized by sperm of Echinus miliaris produces a late larva having anterior epaulettes, posterior epaulettes, no green pigment, one right side dorsal pedicellaria, one right side ventral pedicellaria, one posterior pedicellaria.

These characters are the same as 1 .

3. The egg of Echinus miliaris fertilized by its own sperm produces a late larva having anterior epaulettes, no posterior epaulettes, green pigment, one right side dorsal pedicellaria, one right side ventral pedicellaria, no posterior pedicellaria.

4. The egg of Echinus miliaris fertilized by sperm of Echinus esculentus produces a late larva having anterior epaulettes, no posterior 
epaulettes, green pigment, one right side dorsal pedicellaria, one right side ventral pedicellaria, no posterior pedicellaria.

These characters are the same as 3 .

\section{CHARACTERS OF THE SKELETON.}

While we have already stated that the skeleton is extremely variable, and is a doubtful index of parental influence, what evidence we have been able to derive from the study of a large number of larvæ seems distinctly to bear out some of the more recent contentions. While we reserve the publication of a large number of figures of the skeletal apical rods, we have inserted one typical example of each cross (Fig. 5). Here the evidence would seem to be distinctly in favour of the dominance of one character over another, as brought out by Loeb, King, and Moore (10). For, with reference to Fig. 5, it will be seen that the normal apical skeleton of $E$. esculentus is
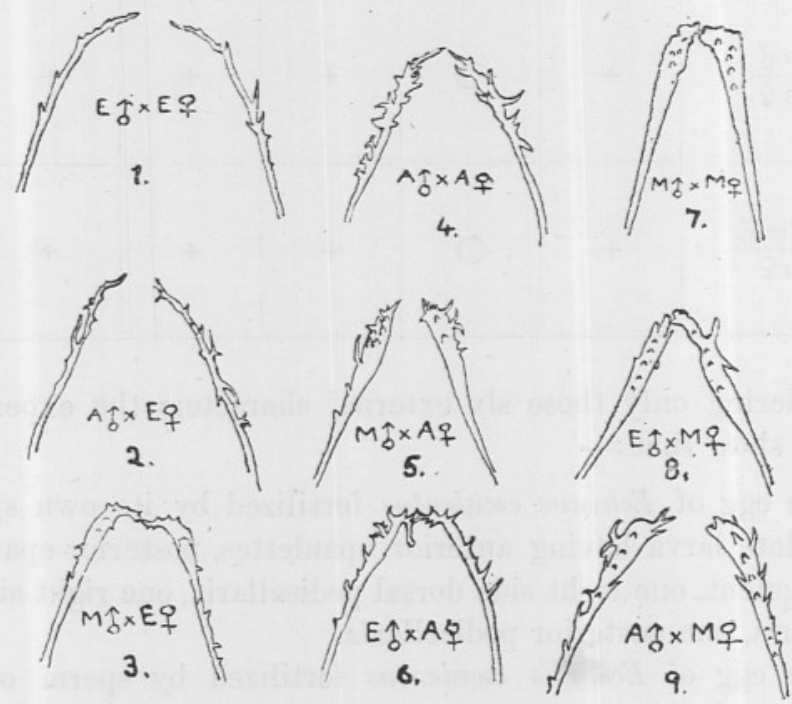

Fig. 5. - Skeletal apical rods of four-armed Plutei. 1. E. esculentus $\delta \times E$. esculentus $\$$. 2. E. acutus $\delta \times E$. esculentus $\$$. 3. E. miliaris $\delta \times E$. esculentus $\$$. 4. $E$. acutus $\delta \times$ E. acutus $\$$. 5. E. miliaris $\delta \times$ E. acutus $\$$. 6. E. esculentus $\delta \times$ $E$. acutus $\$$. 7. $E$. miliaris $\delta \times E$. miliaris $\$ . ~ 8 . ~ E$. esculentus $\delta \times E$. miliaris $\uparrow$. 9. E. acutus $\delta \times E$. miliaris $\uparrow$.

slender, arched, and somewhat spinous, that of $E$. acutus is more robust and bears a greater number of spinous processes, while that of $E$. miliaris is straight and club-shaped, bearing a few blunt knobs.

Loeb states that the spinous condition, as is exhibited for example by $E$. esculentus and $E$. acutus (Fig. 5), is dominant over the smooth, as 
seen in E. miliaris; and that the clubbed condition, like that of E. miliaris, is dominant over the arched form, as that of E. esculentus. This inheritance is stated to take place irrespective of whether the characters are paternal or maternal. This we find to be the case in our crosses, but we also find that the female has a stronger influence on the character of the hybrid skeleton than the male. As an illustration of the dominance of the spinous condition over the smooth, it will be seen in Fig. 5 that in the cross $E$. acutus ${ }^{+} \times E$. miliaris of and its reciprocal the rough condition appears. Again, with regard to the clubbed and arched conditions, in the cross E. esculentus of $\times$ E. miliaris $q$ and its reverse the clubbed form appears in the hybrids. It is also clear from the figure that maternal influence is stronger than the paternal.

\section{THE CHEMICAL CONTROL OF INHERITANCE.}

In 1910 Tennent (18), working at Tortugas, made the cross Toxopneustes $0 \times$ Hipponöe + and its reciprocal, producing hybrid larvæ which had, in both cases, the characteristics of Hipponöe. The skeleton was used as an index of parental influence, and we have already discussed the doubtful value of this evidence. He altered the concentration of the $\mathrm{OH}$-ions in the water in which the fertilizations were made, by adding small definite quantities of Sodium hydrate and of Acetic and Hydrochloric Acid. By this means he claims to have altered the dominance, so that the hybrid skeleton now resembled that of Toxopneustes. While, from a close examination of his figures, it is clear that a considerable percentage of his Plutei showed skeletal abnormalities, his main result may or may not be considered as proved. If it is true, the conclusion is obviously a very important one, and one which should be tested with other material and at other places. For this reason, although the inheritance of the late larval characters of the hybrids at Plymouth is strictly maternal, and is not determined by any particular species, yet these characters are of such a definite nature, that we thought it to be a good opportunity for repeating this work.

With this object the crosses $E$. esculentus o $\times E$. miliaris $q$ and $E$. acutus $\delta \times E$. miliaris $q$, and their reciprocals were made. The eggs were placed in sea-water, the $\mathrm{OH}$-ion concentration of which had been altered by the addition of .25 to $1 \mathrm{cc} . \mathrm{N} / 10 \mathrm{NaOH}$ in the one case, and $\mathrm{HCl}$ or Acetic Acid, in the other, per $200 \mathrm{cc}$. of sea-water. As soon as the blastulae swam to the surface, they were transferred to "outside" or to "Berkefeld sea-water." At the same time, cultures of the same crosses were made, which were fertilized and raised from the commencement in sea-water of the normal $\mathrm{OH}$-ion concentration.

NEW SERIEs,-vol. IX. No. 2. OCTOBER, 1911. 
A large number of larval skeletons were examined at about ten days old, drawings of which will appear in the forthcoming work, but in no case was the inheritance at all affected. At a late stage (30-40 days), again, a large number of Plutei were examined, but in no case could any alteration in the inheritance of the posterior ciliated epaulettes, the pedicellariae or the green pigment masses, be detected. Figs. 6

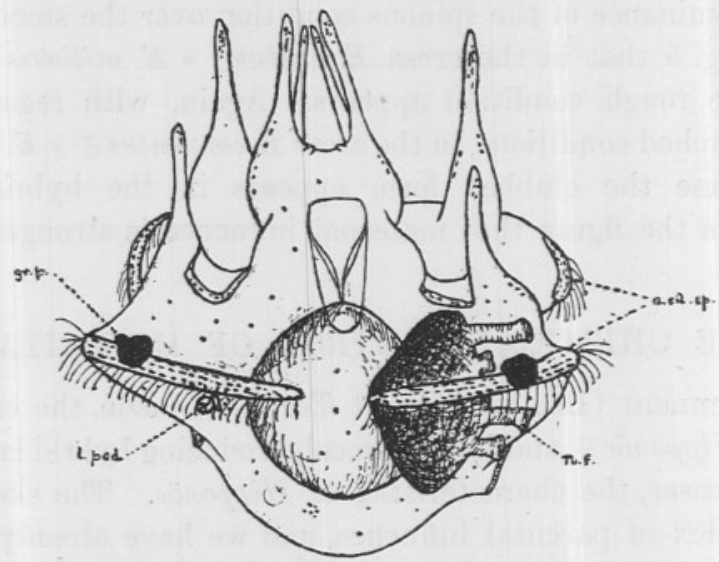

FIG. 6.-Larva of $E$. acutus $\delta \times E$. miliaris $\$$. Dorsal view. 28 days old. Fertilized in water with raised $\mathrm{OH}$-ion concentration. a. cil. ep.-Anterior ciliated epaulette. gr. $p$. -Green pigment. $\quad$ l. ped.-Lateral pedicellaria. tu. f.Tube-foot.

and 7 show typical 28-day Plutei of the cross $E$. acutus $\delta \times E$.

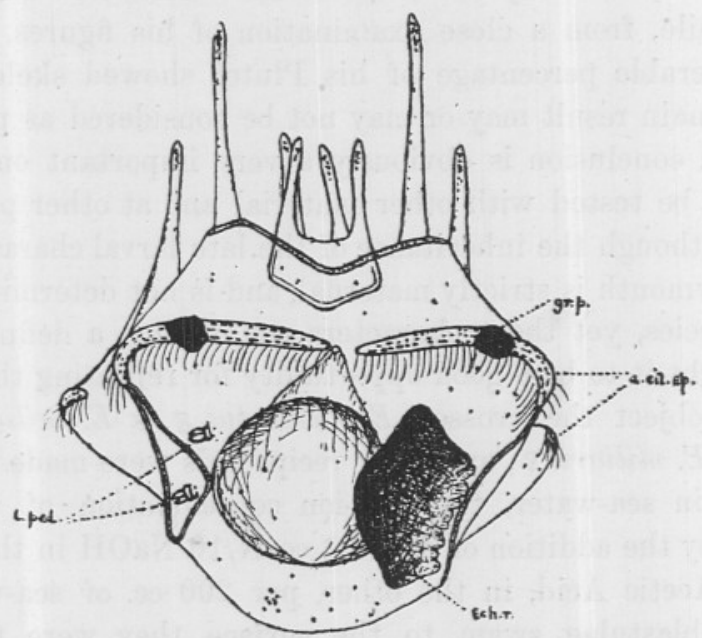

FıG. 7.--Larva of $E$. acutus $\delta \times$ E. miliaris . . Ventral view. 28 days old. Fertilized in water with lowered $\mathrm{OH}$-ion concentration. a. cil. ep.-Anterior ciliated epaulette. ech. $r$.-Echinus rudiment. $g r . p$.-Green pigment mass. $l$. ped. Lateral pedicellaria. 
miliaris $q$ which had been fertilized in water treated respectively with alkali and acid. It will be seen that they differ in no essentials from the hybrids raised in normal sea-water. The inheritance of the maternal pigment masses, absence of posterior ciliated epaulettes and absence of posterior pedicellaria is unchanged.

\section{THE CHARACTERS OF THE YOUNG SEA-URCHIN.}

In all cases the young fully formed Urchins, in superficial features, such as the character of the spines, pigmentation, etc., show a motherly influence, but so far we have not made a close examination of the number and structure of the test plates. The young Urchins always secrete a thick layer of mucus on the surface of the test, which effectually prevents any examination of the plates in the living state, and any such examination necessitates killing the hybrids. We wish to reserve for a future occasion our statements on this head.

There is this important feature about the tube feet of $E$. miliaris, to which attention has been drawn by MacBride (11). He has shown that the young $E$. esculentus and $E$. acutus walk by means of five tube feet, each forming the termination of one of the radial canals, and each provided with a sucker, in the centre of the disk of which is a sense organ consisting of elongated cells. In each radius there are in addition the rudiments of a pair of tube feet, which are mere buds in these species, but in $E$. miliaris these accessory tube feet are functional at metamorphosis. So we have this important distinction between the normal just metamorphosed $E$. miliaris and $E$. esculentus or $E$. acutus, that the former has five principal tube feet and ten secondary ones, while the two latter have only the five principal ones, the secondary ones being entirely rudimentary at this stage. This, therefore, offers a definite index of parental influence after metamorphosis. On this head also we wish to defer our statements, to incorporate them later with the evidence offered by the study of the structure and number of the hybrid test plates.

\section{SUMMARY OF CONCLUSIONS.}

1. As the result of extensive investigation of the early larval history of our various crosses, we have come to the conclusion that these are too variable to afford any definite evidence of parental influence, and especially is this true with regard to the skeleton, heretofore considered the chief index of inheritance.

2. What little evidence we have been able to derive from the study of a very large number of skeletons of both normal and hybrid crosses, seems to show that, while the paramount influence is always maternal, 
there is considerable evidence for the contention put forward by Loeb, King, and Moore (10) that the minor skeletal characters are inherited independently of either parent. We are able to bear out their statement that with regard to the apical rods, the spinous condition of which is dominant over the smooth, and the clubbed condition over the arched, quite independently of their origin either from the paternal or the maternal side.

3. Regarding the early larval characters, therefore, as of too variable a nature, we have reared the normal and hybrid crosses to the young Urchin stage, in the hope of finding, in the late development, more definite characters for the solution of the question of inheritance. In the presence or absence of the posterior ciliated epaulettes, of the green pigment masses and of the posterior pedicellaria, we claim that we have found such definite characters, and we find them to be invariably inherited through the egg. A full summary of these facts has already been given in $\S \mathrm{IV}$, page 135 .

4. We have shown that an alteration of the alkalinity of the water affects the inheritance neither of the skeletal characters nor of those of the late larva.

5. The young hybrid Urchins, some of which have already reached a considerable size and are now two years old, are, in superficial appearance, of the pure motherly type.

6. We suspect that a considerable amount of hybridization occurs under natural conditions between $E$. esculentus and $E$. acutus.

\section{LITERATURE.}

1. Allen, E. J., and Nelson, E. W. On the Artificial Culture of Marine Plankton Organisms. Journ. Marine Biol. Assoc. Vol. vII, p. 421. 1910.

2. Bell, F. J. Catalogue of the British Echinoderms in the British Museum. London. 1892.

3. Boveri, T. Ein geschlechtlich erzeugte Organismus ohne mütterliche Eigenschaften. Ber. d. Gesf. Morph. u. Phys. München. 1889.

4. _ Über die Befruchtungs und Entwickelungsfähigkeit kernloser Seeigeleier und über die Möglichkeit ihrer Bastardierung. Arch. für. Ent. Mech. Vol. II, p. 394. 1895.

5. Doncaster, L. Experiments on Hybridization, with special reference to the effects of conditions on Dominance. Phil. Trans. Roy. Soc., London. Ser. B. Vol. cxcvi, p. 119. 1903.

6. Driesch, $\mathrm{H}$. Über rein mütterliche Charaktere an Bastardlarren von Echiniden. Arch. für Ent. Mech. Vol. viI, p. 65. 1898.

7. —— Über Seeigelbastarde. Arch. für. Ent. Mech. Vol, xvi, p. 713. 1903.

8. Fischel, A. Über Bastardierungsversuche bei Echinodermen. Arch, für Ent. Mech. Vol. xxiI, p. 498. 1906.

9. Hagedoorn, A. L. On the purely motherly character of the hybrids produced from the eggs of Strongylocentrotus. Arch. für Ent. Mech. Vol. xxvII, p. 1. 1909. 
10. Loeb, Jacques, King, W. O. R., and Moore, A. R. Uber Dominanzerscheinungen bei den Hybriden Pluteen des Seeigels. Arch. für Ent. Mech. Vol. xxIx, p. 354.1910.

11. MacBride, E. W. The development of Echinus esculentus, together with some points in the development of E. miliaris and $E$. acutus. Phil. Trans. Roy. Soc., Lond. Ser. B. Vol. cxcv, p. 285. 1903.

12. Morgan, T. H. The fertilization of non-nucleated fragments of Echinoderm eggs. Arch. für Ent. Mech. Vol. II, p. 268. 1895.

13. Mortensen, Th. Die Echinodermlarven der Plankton Expedition, p. 68. 1898.

14. —Ingolf" Echinoidea. Vol, I, p. 162. 1903.

15. Echinological Notes. Saertryk af Vidensk. Medel. fra den naturh. Foren i Kbhon. 1911.

16. Seeliger, O. Giebt es geschlechtlich erzeugte Organismen ohne mütterliche Eigenschaften? Arch. für Ent. Mech. Vol. I, p. 203. 1894.

17. Steinbruck, H. Über Bastardbildung zwischen Strongylocentrotus und Sphaerechinus. Arch. für Ent. Mech. Vol, xIv, p. 1. 1902.

18. Tennent, D. H. Echinoderm Hybridization. Papers from the Tortugas Lab. of the Carnegie Inst. of Wash. Vol, III, p. 117. 1911.

19. Vernon, H. M. Effects of Environment on Echinoid Larvæ. Phil. Trans. Roy. Soc., Lond. Ser. B. Vol. clxxxvi, p. 577. 1895.

20. The Relation between the Hybrid and Parent forms of Echinoid Larvæ. Phil. Trans. Roy. Soc., Lond. Ser. B. Vol. cxc, p. 465. 1898.

21. - Cross-fertilization among Echinoids. Arch. für Ent. Mech. Vol. Ix, p. 464.1900. 